Дуња Радојевић

Балканолошки институт САНУ Београд dunjaradojev@gmail.com
УДК 811.161.1'27:811.163.41'27

https://doi.org/10.18485/slavistika.2021.25.2.23

Прегледни рад

примљено 6.3.2021.

прихваћено за штампу 6.10.2021.

\title{
КОМУНИКАЦИОНА КУЛТУРА КАО ПРЕДМЕТ КОНФРОНТАЦИОНИХ РУСКО-СРПСКИХ ИСТРАЖИВАЬА
}

У центру пажње овог рада налази се истраживање комуникационих култура. За главни задатак одређен је приказ резултата међународног пројекта Коммуникативное поведение славянских народов, који је организовао Центар за комуникациона истраживања у Вороњежу у сарадњи са Катедром за славистику Београдског универзитета. Комуникациона култура је у овом раду приказана из угла два народа, српског и руског, те обухвата најзначајније резултате истраживања еминентних српских и руских филолога, објављене у зборницима поменутог пројекта. Разноврсност приступа и истраживачких метода који су у зборницима презентовани није дозволила представљање свих резултата који се односе на српску и руску комуникациону културу. Из тог разлога одлучили смо да представимо детаљније она истраживања која се односе на стандардне комуникационе ситуације са кратким освртом на остале радове, који би у својој разноврсности и сложености морали бити предмет истраживања по обиму много веће публикације.

Кључне речи: пројекат, комуникационо понашање, комуникациона култура, руски језик, српски језик, комуникационе ситуације.

This paper presents a whole set of activities in the Center for Communication Research of Voronezh State University, under the direction of Joseph Abramovich Sternin, professor of general linguistics and stylistics. His field of research encompasses the monographic and co-authored publications with associates from Voronezh State University, as well as a compendium series as part of an international project Communicative Behavior of Slavic Nations, organized in cooperation with the Slavic Department at the University of Belgrade. Communication culture is presented from the angle of two Slavic languages, Russian and Serbian, and thus includes the models of communication behavior in their complexity and diversity, as well as interpretation from the aspect of learning related languages.

Keywords: project, communication behaviour, communication culture, Russian language, Serbian language, communicative situations.

Описивање комуникационе културе утемељено је на истраживањима читавог низа наука: етнографије, етнологије, социологије, психологије, лингвистике, лингвокултурологије, психолингвистике, социолингвистике, паралингвистике, теорије комуникације, реторике и др. Њен задатак је синтеза филолошких и социоантрополошких наука и изградња целовите слике националног комуникационог понашања једног народа (Прохоров и др. 2006:19). Описивање језика као културног феномена захтева и описивање комуникационог понашања као његовог саставног дела. Са развојем антрополошке лингвистике повећала се разноврсност приступа и интересовање за системско описивање комуникационог понашања, како на нивоу целе једне националне културе, тако и у њеним саставним деловима. 
Почетком деведесетих година XX века, решавању питања комуникационе културе велику пажњу посветила је Катедра опште лингвистике и стилистике Универзитета у Вороњежу. Теме се односе на општа питања, као што је дефинисање појма комуникационо понашање/култура и описивање основних модела комуникационог понашања, затим на руску комуникациону културу посматрану самостално, али и кроз призму других националних комуникациони култура. У првој деценији XXI века истраживање је попримило међународни карактер, организовањем пројекта Коммуникативное поведение славянских народов, у сарадњи са Београдским универзитетом, добивши тиме заслужено место у оквиру лингвистичке славистике. Главни циљ овог рада јесте промовисање резултата истраживања у оквиру овог пројекта, као и указивање на њихов значај за дефинисање образаца комуникације између представника два сродна словенска народа.

Прво успешно дефинисање термина комуникационо понашағе везује се за име Јосифа Абрамовича Стерњина (Иосиф Абрамович Стернин), аутора брошуре Модели описания коммуникативного поведения. ${ }^{1}$ Дефиниција у овој публикацији гласи: „Под комуникационим понашањем подразумева се укупност норми и традиција општења народа, друштвене, узрасне, полне, професионалне и сл. групе, али и појединачне личности" (Стернин 2000: 3). Према каснијим дефиницијама под комуникационом културом се подразумева понашање човека при вербалном или невербалном чину, регулисано правилима којих се он као личност придржава, тј. укупност норми и правила комуникације (Прохоров и др. 2006). Повећавањем актуелности ове научне дисциплине и обима истраживања, ширио се и терминолошки апарат, те у овом тренутку садржи више десетина појмова, којима су обухваћени методи, принципи и модели описивања, могућности класификације и слично (Стернин 2000: 4-9).

Када говоримо о комуникационом понашању одређене етничке групе, користимо термин национална комуникациона култура. Адекватно комуникационо понашање је показатељ развоја појединца, несумњиво важан део сваке националне културе и један од основних „материјала” којима се гради општа слика приликом контакта са другим народима, па би свест о његовом неговању и развијању требало да има сваки члан одређеног језичког колектива.

Комуникација се често одвија у типским ситуацијама, уз употребу стандардних говорних средстава, а узимајући у обзир одређене околности: да ли се разговор одвија насамо или у присуству других лица, у добро познатом или непознатом амбијенту и сл. У науци су описана четири основна принципа националног комуникационог понашања: 1. комплексност; 2. контрастивност; 3 . коришћење метајезика који није строго одређен (рус. нежесткий метаязык) и 4. разграничавање комуникационе норме и комуникационе праксе (Стернин 2000: 9-13). Дефинисање параметара, фактора и модела националног комуникационог понашања веома је важан и захтеван научни задатак. Према резулта-

\footnotetext{
${ }^{1}$ Поменута брошура објављена је у два маха, првобитно 2000. године, у обиму од 27 страница, а затим 2015. године излази и допуњено издање, обима 52 странице. Међутим, неопходно је напоменути да је Ј. А. Стерњин исту дефиницију предложио још 1989. године (в. Стернин 1989).
} 
тима истраживања могуће је уочити три основна модела описивања комуникационог понашања, који се разликују превасходно у намени, а заједничка им је комплексност описа: ситуациони, аспекатски и параметарски (Стернин 2000: 14-17).

Приликом контакта између различитих лингвокултуролошких заједница одвија се интеркултурна комуникација. На успешност реализације комуникације између различитих народа суштински утиче степен разумевања разлика у националним стереотипима. Ако ово разумевање изостане, у условима непосредног контакта између припадника различитих националних култура или различитих вредносно-идејних група може доћи и до појаве комуникацијског шока, који доводи до неспоразума, конфликта, реакције чуђења или протеста, па и прекидања комуникације (Прохоров и др. 2006). Дакле, неопходан је и теоријски и практични приступ истраживању, са циљем издвајања оних компонената комуникације у којима су карактеристике националног менталитета најизраженије (Прохоров и др. 2006).

Истраживање комуникационе културе нашло је простор и примену у другим научним дисциплинама, као што су лингводидактика и методика наставе. Методолошка парадигма описа националног културног понашања обрађена у Центру за комуникациона истраживања у Вороњежу дала је значајан потенцијал за примену у методици наставе руског језика као страног. У српској говорној средини ову парадигму описала јеРајна Драгићевић (2010), у оквиру монографије Вербалне асоцијащије кроз српски језик и културу, ${ }^{2}$ док је њеној примени у сакралној сфери посвећена монографија Ксеније Кончаревић (2013) Сакрална комуникација: норме, традиције, средства. ${ }^{3}$

Изучавање говорне етикеције сродних језика веома је значајно и из угла спречавања језичке и лингвокултуралне интерференције (Вићентић 2014: 95). Примена конфронтационе анализе при учењу страног језика базира се на принųипу билатералности. Приликом билатералног конфронтирања веома је битно да студенти буду што детаљније упознати са одликама обеју култура, своје матерње и културом језика који уче. На тај начин, искористиће предности позитивног трансфера, фацилитације, али и избећи замку интерференције, негативног трансефера (Кончаревић 2014: 17-26). Националне специфичности могу изазвати чуђење, недоумицу, неадекватну интерпретацију, чак и комуникациони шок, док су сличности битне једино ако подстичу позитиван трансфер комуникационих радњи. У центру пажње лингводидактичких истраживања требало би да буде нормативно комуникационо понашање у датој култури, а потом и поступци избегававања грешака изазваних утицајем матерње комуникационе културе. Приликом учења страног језика говорне обрасце увек треба усвајати ин-

${ }^{2}$ Четврто поглавље ове књиге (Драгићевић 2010: 99-151) садржи поређење језгра језичке свести у руском и српском језику, као и анализу комуникационог идеала Руса и Срба. Сва истраживања повезује анализа вербалних асоцијација говорника различитих словенских језика. Таква испитивања представљају освежење и новину у методолошком приступу лексичком значењу.

${ }^{3}$ Многобројни аспекти сакралне сфере последњих деценија добијају шира и изузетно утемељена научна тумачења, чему К. Кончаревић овом монографијом даје вредан прилог. 
тегрално са невербалним аспектом комуникације, гестовима и мимиком, што је једини начин за формирање целовите слике комуникационог понашања.

Национално комуникационо понашање тражи систематичан опис, који би био израђен на основи одређеног теоријског модела. Горе поменути модели (ситуациони, аспекатски и параметарски) показали су своју ефикасност када говоримо о опису несродних националних култура, међутим, није било описа који би обухватили сродне националне комуникационе културе (Пипер, Стернин 2004: 3). Непостојање истраживања било је подстицај истакнутим славистима, а као резулатат дугогодишњег рада дало је резултате од кључне важности и полазну тачку за многа будућа истраживања.

Пројекат Комуникационо понашање словенских народа, организован у периоду од 2004. до 2007. године под руководствомЈосифа Абрамовича Стерњина и Предрага Пипера пример је веома успешне међууниверзитетске сарадње Центра за комуникациона истраживања при Вороњешком државном универзитету и Катедре за славистику Београдског универзитета. У пројекту је учествовала група истакнутих српских лингвиста и слависта: Предраг Пипер, Ксенија Кончаревић, Људмила Поповић, Биљана Вићентић, Рајна Драгићевић, Дарја Војводић и др. Резултат плодотворне делатности учесника и сарадника пројекта је пет зборника у чијем оквиру је објављен велики број научних радова из области руске и српске комуникационе културе.

Сваки од зборника у погледу садржаја подељен је на више целина: национална специфика комуникативног понашања, национални говорни етикет, комуникациони жанрови, језичка свест итд. Чланци који се односе на руско-српско комуникационо понашање заступљени су у свакој од наведених целина. У три зборника (бр. 19, 22 и 28) објављен је велики број радова, различитих по обиму, садржају, методологији и аспектима, али са заједничким општим циљем - стицање свеобухватне слике о сличностима и разликама у комуникационом понашању два сродна народа.

У тематском смислу радови обухватају оне који се односе на гестове и фразеологију у комуникационој култури (Попович 2004), експериментална и асоцијативна истраживања о поимању придева руски и етнонима Руси у свести Срба (Пипер 2004; Правда, Яурова 2004). Међу експерименталним истраживањима важно место у пројекту заузело је и оно које се односи на идеалног саговорника у свести представника српске и руске комуникационе кулутре (Драгичевич 2004).

Анализирајући јавне натписе у руско-српском комуникационом понашању свој изузетан прилог пројекту је дала Људмила Поповић радом «Дискурс публичных надписей в коммуникативном поведении русских и сербов» (Попович 2006). Описана је и комуникема у процесу општења, а на материјалу емотивних исказа (Маслова 2004). Пословицама, као веома важном делу народног стваралаштва, пажњу је посветила Д. Војводић у раду «Русская и сербская языковые картины мира через призму количественных отношений в паремиях» (Войводич 2007, стр: 152-169).

Да је комуникациона култура научна дисциплина која своју примену налази у свим областима живота и друштвеним групама, показала је К. Кончаревић, 
која је ситуациони модел комуникационог понашања применила на описивање комуникације у сакралној сфери (Кончаревич 2006). Пре него што пређемо на централни део овог рада, поменућемо и чланак «О языках, «помнящих» и «не помнящих» родства (из наблюдений над системой родствав русском и сербском языках)»(Влашкалич, Войводич 2004), чији аутори Ј. Влашкалић и Д. Војводић на веома сугестиван начин указују на значај неговања, очувања и сталан развој родбинских односа, као једне од најзначајнијих идентификационих карактеристика сваког народа.

Из горе наведеног видљива је већ поменута разноврсност тема и приступа, али је јасна и немогућност да се сваком од радова у малим оквирима посвети једнака пажња. Међутим, у зборницима примећујемо и оне радове који су слични садржајем, а односе са на комуникационо понашање припадника српске и руске лингвокултуролошке заједнице у стандардним комуникационим ситуацијама, што је одредило основни циљ овог рада, а то је упоредно представљање резултата до којих су у својим истраживањима поједини учесници пројекта дошли, користећи приликом описа махом ситуациони модел описивања. Број у радовима описаних комуникационих ситуација је веома широког дијапазона, али ћемо се ми ограничити на следеће: обраћање, сусрет, представљање, опраштање, извињавање и захваљивање. Свакако и остале комуникационе ситуације заслужују једнаку пажњу и драгоцен су извор за стицање целокупније слике о сличностима и разликама у националном комуникационом понашању Руса и Срба, те ће бити набројане како би подстакле будуће истраживаче да се њима потенцијалано баве у научним истраживањима ширег обима.

На самом почетку навешћемо веома битан закључак двојице организатора пројекта, П. Пипера и Ј. А. Стерњина , изнет у чланку «О контрастивном изучении коммуникативного поведения близкородственных народов (русская и сербская коммуникативные культуры)» (Пипер, Стернин 2004), а који се односи на потешкоће у описивању и поређењу руске и српске комуникационе култуpe: степен сличности ова два језика је изузетно висок, истраживање у пракси не показује никакве ендемичне или лакунарне комуникационе чињенице и појаве, те се у већини случајева о разликама не може говорити из угла присуства/отсуства одређене појаве, већ у смислу учесталости или степена манифестовања у комуникацији (Пипер, Стернин 2004: 3).

Говорећи о правилима бонтона као врсти лозинке, тј. кода који проверава да ли постоји разумевање између саговорника, Б. Вићентић у раду «Речевой этикет у сербов и русских» (Вичентич 2004) анализира грешке до којих долази услед језичке интерференције, погрешног одабира и употребе одређених облика.

Ауторка још једног од радова који садржи конфронтациону анализу рускосрпске комуникационе културе у горе наведеним типским ситуацијама је Е. А. Правда (2004) која у чланку «Некоторые особенности коммуникативного поведения представителей сербскоязычной культуры» говори о историјским околностима у прошлости које су довеле до формирања снажног осећаја националне свести код припадника српске лингвокултуролошле заједнице, али и о високој политизованости српског друштва, о заштитничкој улози Русије у свести Срба и сл. Зато би приликом поређења српске и руске комуникационе културе треба- 
ло узети у обзир не само сродност језика, као припадника словенске групе, већ и сродност душа, осећај братства и вишевековно руско-српско пријатељство.

У наставку ћемо систематизовати најважније закључке спроведених истраживања који се односе на горе наведене типске комуникационе ситуације.

\section{Обраћање.}

Сваки разговор почиње од обраћања будућем саговорнику, усмеравањем погледа окретањем главе у правцу истог. О томе сведочи и сам руски израз обратить, у значењу повернуть (голову) - окренути главу, усмерити поглед у правцу саговорника (Вичентич 2004: 96). На избор средстава вербалне комуникације утиче читав низ фактора: узраст, пол, професија учесника у говорном чину, природа односа (познаник или странац), околности разговора (званичан или незваничан) и сл. Обраћање се у српском језику разликује од руског по квантитету могућих варијанти, али и по структури и учесталости употребе појединачних облика. Разлог томе је, између осталог, и одсуство вокатива у руском језику са једне стране, а са друге одсуство патронима у српском (Пипер, Стернин 2004: 4). Такође је битно нагласити да је у руском бонтону обраћање именом и патронимом одраз учтивости, културе, уважавања саговорника (Вичентич 2004: 98).

Стандардна и општеприхваћена формула за обраћање странцима у српској говорној средини је: мушкарцу - господине, удатој (или старијој) жени госпођо, а неудатој (младој жени и девојци) - госпођицее (Правда 2004: 78). Српско обраћање у форми господине и госпођо чешће се користи од руских еквивалената господин и госпожа, а истовремено је руска форма обраћања са женщиина у српском језику ретка и изузетно експресивна (Пипер, Стернин 2004: 4). Са друге стране, ни у руском говорном бонтону обратити се непознатим особама са мужчина или женщзина не сматра се пристојним, али је облик усвојен услед непостојања прикладније форме која би се користила у датој ситауцији (Вићентић 2004: 97). Врло учтивим и свечаним обраћањем групи људи у обе комуникационе културе сматра се израз даме и господо (рус. дамы и господа) (Вичентич 2004: 97).

При избору речи којима ћемо се обратити непознатом лицу у оба језика важну улогу игра узраст саговорника. У српском се користе следећи изрази: девојчице, девојко, иуро, дечко, младићу, дете (децьо у множини), чему су у руском еквиваленти девочка, девушка, (девчонки, девчата), мальчик, молодой человек, дети. Веома интенресантно правило наводи Б. Вићентић: приликом обраћања једном детету у српском се користи реч дете, док је у руском обавезно именовање по полу мальчик или девочка (никада ребенок), а групи - дети. Облик ребята користи се приликом пријатељског обраћања групи младих (момака и девојака) или само момака (Вичентич 2004: 97).

Е. А. Правда уочава у српском језику и бележи у свом раду неке облике традиционалних обраћања терминима за родбинске везе: младом (млађем по узрасту) човеку - сине (сын, сынок), старијем човеку - деда (дедушка), док се, рецимо, дете старијој мушкој особи може обратити са чико (дядя) (Правда 2004: 78). Интересантно је, такође, поменути српске народне изразе обраћања непозан- 
тима типа: земљаче, пријатељу, пријо, којима се користе више мушкарци него жене. Слично је и код Руса: приятель, земляк, братец (Вичентич 2004: 98), а навешћемо и српску шаљиву форму обраћања: брате (брат, браток), која се користи у обраћању како мушкарцима, тако и женама, али и облике: пријатељу (друг, приятель), човече (человек) и сл. (Правда 2004: 79).

Веома интересантно и са мноштвом специфичности у обе комуникационе културе (српској и руској) јесте обраћање по професији. Само у српској говорној средини широко је распростањено обраћање продавца купцу са комшија и комшинице (рус. сосед и соседка), посебно у прехрамбеним продавницама, на киосциома и на пијаци, без обзира на то да ли купац заиста живи у близини (Пипер, Стернин 2004: 4). Такође се и купац на исти начин може обратити продавцу. У превозним средствима, возача је оштеприхваћено називати мајсторе (рус. мастер) (Пипер, Стернин 2004: 5). Истим обликом Срби се обраћају и водоинсталатерима, електричарима, занатлијама и сл. (Вичентич 2004: 98). У руској комуникационој култури скрећемо пажњу на употребу израза девушка код обраћања продавачицама и службеницама - женама уопште - независно од узраста (Вичентич 2004: 97).

Срби се много чешће обраћају саговорнику по професији: учитељу, учитељиие, наставниче, наставнице, професоре, професорка, докторе, сестро, директоре, док се у Русији на тај начин обраћају само докторима и медицинском особљу: доктор, сестра, нянечка и сл. (Вичентич 2004: 98).

Истраживања су показала да се и Руси и Срби по могућности у конкретној говорној ситуацији приликом обраћања непознатом саговорнику или случајном пролазнику труде да избегну директно обраћање (Вичентич 2004: 97). Чешћи су у употреби следећи облици: извините, опростите, молим Вас, тј. форме којима скрећемо пажњу на себе, али се и извињавамо саговорнику на сметњи. У руском бонтону постоје еквиваленти извините, пожалуйста, простите, будьте добры, будыте любезны, али су много учесталија питања-молбе облика: Не скажете..? Не подскажете..? Скажите пожалуйста..?. Интересантан је и српски израз Да вас питам...?, у ком су модални глаголи попут хоћу, желим, могу ли, смем ли изостављени (Вичентич 2004: 97).

Оваквим облицима је у свом раду «Конвенциональные косвенные директивы в форме вопроса (на материале русского и сербского языков)» посветила пажњу А. Маслова (2007). Питање са значењем намере ауторка је окарактерисала као канонски пример конвенционалног индиректног перформатива (Маслова 2007: 125). Употреба питања са негацијом за матерње говорнике руског језика сасвим су уобичајени облици учтиве молбе: У вас нет... ? Не могли бы вы...? Bbl не скажете...? Не будете ли вы так любезны...? Ове конструкције у српском језику нису честе, али је и улога негације другачија од оне у руском језику. Док у руском она има карактер учтиве молбе, у српском може нагласити дистанцу међу саговорницима или званичну природу комуникације (Маслова 2007: 125). У поређењу са руском конструкцијом Не могли бы вы мне помочь? у српском језику се предност даје облику без негације: Можете ли ми помоћи? / Да ли бисте могли да ми помогнете? 
Успостављање контакта.

У интеракцији представника различитих култура једна од најуочљивијих појава је успостављање контакта, којој је П. Пипер (2006) посветио пажњу у раду «Как дела? О контактоустанавливающих диалогах в русском и сербском языках». Уводни дијалози приликом успостављања контакта могу се сматрати посебним говорним жанром, аутономне су дијалошке структуре, које поседују специфичности у погледу форме и комуникационе функције (Пипер 2006: 3). Ови дијалози, чешћи у српском него у руском језику, дуго су били на периферији интересовања научника (Пипер 2006: 3), а одликују се асиметријом, из разлога што једно исто питање по правилу може да има много више од једног одговора. ${ }^{4}$ У руском језику дијалози за успостављање контакта почињу најчешће од питања Как дела?. Одговори се разликују по бројним критеријумима: стереотипни су и оказионални, високо и нискофреквентни, експресиви и неутрални. Са друге стране, у српској комуникационој култури одговори на питање Како cme? у основи су стереопипни, устаљени, неутрални, али и индивидуализовани уз одређену дозу хумора или неки говорни клише (Пипер 2006: 8). Функција питања Како си/сте? чешће је успостављање контакта, него истинска заинтересованост како се саговорник осећа (Пипер, Стернин 2004: 4).

\section{Поздрав.}

Поздрав је веома битан чин и фактор у комуникацији. Великом се увредом сматра игнорисање познананика, те се поздрав сматра минимумом комуникације (Вичентич 2004: 98). У функцији неутралних поздрава код Срба, а у зависности од доба дана користе се облици: добро јутро, добар дан, добро вече. У руском језику такође постоје доброе утро, добрый день, добрый вечер, али нису директни еквиваленти српским изразима (Вичентич 2004: 99). Српској форми здраво одговарају руске здравствуй и привет, те ове изразе користе познаници, тј. они који су „на ти”. Супротност је српски израз ми смо на здраво-здраво, за не тако блиска познанстава (Вичентич 2004: 98).

У фукнцији наставка комуникације, после поздрава и покретања дијалога питањем Како си(сте)? (рус. Как дела?) у српској говорној заједници следе питања: Шта има ново? Како је?. Најфреквентнији одговори су добро, није лоше, а врло је чест одговор ништа (Вичентич 2004: 99). На руска еквивалентна питања: Что нового? Как жизнь? Какие новости? Как успехи? (Ну), как тыл? такође следе неутрални одговори ничего, нормально, так себе, потихонечку, хорошо (Вичентич 2004: 99).

Сусрет познаника после дуго времена обилује фразеолошким изразима. Срби говоре: Где си, одавно (дуго)се нисмо видели? Сто година (Целу вечност) се нисмо видели!, док су руски еквивалентни изрази; Сколько лет, сколько зим! Давно (сто лет) тебя не видел! Где ты пропадал? (Вичентич 2004: 99).

Ако смо изненађени сусретом са познаником на неочекиваном месту рећи ћемо: Откуд ти (овде)? Кога ја то видим?! Кога то виде моје очи?! (рус.:

${ }^{4}$ У поменутом раду П. Пипер алфабентим редом наводи списак потенцијалних одговора на пињања Как дела? и Како си?/сте? (в. Пипер 2006: 6-8). 
Какими судьбами! Вот не ожидал! Какая неожиданность! Кого вижу?! Какая встреча! Как ты сюда попал?! Как вы оказались здесь?!, а забележени су и интересантни (са лингвистичке тачке гледишта) покушаји да се избегну стандардни и стереотипни одговори, тежи се оригиналности (Вичентич 2004: 100).

\section{Опраштање.}

Приликом опраштања Срби говоре довиђењ $а$, чему одговара руски облик до свидания. Омладина користи и изразе здраво (ајде здраво) и ћао, док се у руској говорној заједници у истим околностима користи израз пока (често са речцом: ну) (Вичентич 2004: 99). У функцији опраштања често се користе и жељепоздрави облика: счастливо, всего доброго, всего хорошего, чији српски еквиваленти наглашавају учтивост и уважававање саговорника, а гласе: све најбоље или пријатно (Вичентич 2004: 99). Интересантно је поменути и чест израз видимо се (садашње време употребљено у функцији будућег). Распрострањеност ове форме потврђује и постојање сличног израза - чујемо се (Вичентич 2004: 100). Руски еквивалент изразу видимо се био би до встречи.

У Србији нема руског обичаја да се још мало поседи пред одлазак (Пипер, Стернин 2004: 5). На неким локалитетима у српским селима уобичајено је избегавати дуга и церемонијална опраштања са пријатељима који одлазе јер се верује да се у супротном никада неће вратити (Правда 2004: 79).

Извињавање и захваљивање.

Срби се чешће него Руси захваљују за ситне услуге, врло често као израз учтивости. У руској комуникационој култури захваљивање је ређе, а функција је буквална - захвалност за помоћ, услугу и сл. (Пипер, Стернин 2004: 6). Слична је и улога осмеха, односно за Русе типична бытовая неулыбчивость, која је једна од најизраженијих и најспецифичнијих одлика руске комуникационе културе (Стернин 2004: 12). Ни код Срба се не практикује церемонијално извињавање и осмехивање на сваком кораку, али је у суштини често, услед пријатељске настројености српског народа (Правда 2004: 79).

Осим наведених и описаних комуникационих ситуација у зборницима пројекта Комуникаиионо понашағе словенских народа описано је од стране признатих стручњака мноштво типских ситуација: комуникација у јавности, са децом, у образовним установама, јавни натписи, забране, упозорења, изражавање (не)сагласности, симболика пољупца, загрљаја, боје, мириса и низ сличних ситуација. Као што смо већ навели, чинило се немогућим дотаћи се сваке комуникационе ситуације или теме описане у зборницима, чак ни када бисмо то покушли да урадимо у основним цртама и пуким набрајањем. Одабир који смо направили односи се на основно успостављање контакта, који је, као што смо у тексту и навели, предуслов за наставак сваке комуникације.

Свакако остаје жеља и нада да ће конфронатационо истраживање српске и руске комуникационе културе привући пажњу што већег броја истраживача, те да ће бити што детаљније описани и размотрени и до сада неразјашњени аспекти. 


\section{Цитирана литература}

Вичентич, Биляна. «Речевой этикет у сербов и русских». [В:] П. Пипер, И. А. Стернин (ред.) Коммуникативное поведение словянских народов. Вып. 19. Воронеж: Востоки, 2004, 95-101.

[Vichentich, Bili`ana. «Rechevol ètiket u serbov i russkikh». [V:] P. Piper, I. A. Sternin (red.) Kommunikativnoe povedenie slovi ${ }^{\curvearrowright}$ anskikh narodov. Vyp. 19. Voronezh: Vostoki, 2004, 95-101]

Войводич, Даря. «Русская и сербская языковые картины мира через призму количественных отношений в паремиях». [В:] И. А. Стернин, Л. Шипелевич (ред.) Коммуникативное поведение. Вып 28: Коммуникативное поведениеславянских народов (русские, украинцы, белорусы, поляки, сербы). Варшава: Институт русистики 2007, 167-184.

[Vojvodič, Darâ. «Russkaâ i serbskaâ âzykovye kartiny mira čerez prizmu količestvennyh otnošenij v paremiâh». [V:] I. A. Sternin, L. Šipelevič (red.) Kommunikativnoe povedenie. Vyp 28: Kommunikativnoe povedenieslavânskih narodov (russkie, ukraincy, belorusy, polâki, serby). Varšava: Institut rusistiki 2007, 167-184]

Драгићевић, Рајна. Вербалне асоцијације кроз српски језик и културу. Београд: Друштво за српски језик и књижевност Србије, 2010.

[Dragićević, Rajna. Verbalne asocijacije kroz srpski jezik i kulturu. Beograd: Društvo za srpski jezik i književnost Srbije, 2010]

Влашкалич, Ясмина, Дойчил Войводич. «О языках, «помнящих» и «не помнящих» родства (из наблюдений над системой родства в русском и сербском языках)». [B:] П. Пипер, И. А. Стернин (ред.) Коммуникативное поведение словянских народов. Вып. 19. Воронеж: Востоки, 2004, 203-216.

[Vlaškalič, Âsmina, Dojčil Vojvodič. «O âzykah, «pomnâŝih» i «ne pomnâŝih» rodstva (iz nablûdenij nad sistemoj rodstva v russkom i serbskom âzykah)». [V:] P. Piper, I. A. Sternin (red.) Kommunikativnoe povedenie slovânskih narodov. Vyp. 19. Voronež: Vostoki, 2004, 203-216]

Драгичевич, Райна. «Сербский коммуникативный идеал в сопоставлении с русским (экспериментальное исследование коммуникативного поведения)». Перевод на рус.: Б. Мишкович. [В:] П. Пипер, И. А. Стернин (ред.) Коммуникативное поведение словняских народов. Вып. 19. Воронеж: Истоки, 2004, 90-95.

[Dragichevich, Raĭna. «Serbskiı̌ kommunikativnyĭ ideal v sopostavlenii s russkim (èksperimental'noe issledovanie kommunikativnogo povedenii ${ }^{2}$ a)». Perevod na rus.: B. Mishkovich. [V:] P. Piper, I. A. Sternin (red.) Kommunikativnoe povedenie slovni ${ }^{\wedge}$ askikh narodov. Vyp. 19. Voronezh: Istoki, 2004, 90-95]

Кончаревич, Ксенија «Коммуникативное поведение монашествующих в сербской речевой и социокультурной среде (ситуативная модель анализа)». [В:] П. Пипер, И. А. Стернин (ред.) Коммуникативное поведение словянских народов. Вып. 22. Воронеж: Истоки, 2006, 28-54.

[Končarevič, Ksenija «Kommunikativnoe povedenie monašestvuûsih v serbskoj rečevoj i sociokul'turnoj srede (situativnaâ model' analiza)». [V:] P. Piper, I. A. Sternin (red.) Kommunikativnoe povedenie slovânskih narodov. Vyp. 22. Voronež: Istoki, 2006, 28-54]

Кончаревић, Ксенија. Сакрална комуникација: норме, традиције, средства. Београд: Православни богословски факултет, 2013.

[Končarević, Ksenija. Sakralna komunikacija: norme, tradicije, sredstva. Beograd: 
Pravoslavni bogoslovski fakultet, 2013]

Кончаревич, Ксения. «Лингводидактический аспект сопоставительного изучения русской и сербской коммуникативных культур». Русский язык как инославянский 6, 2014: 17-26.

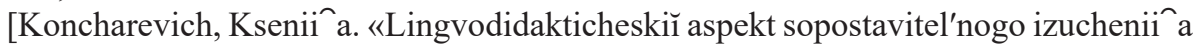

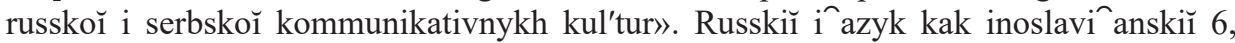
2014: 17-26.]

Маслова Алина Ю. «Коммуникема как компонент процесса общения (на материале эмотивных высказываний в русском и сербском языках)». [В:] П. Пипер, И. А. Стернин (ред.) Коммуникативное поведение. Вып. 19. Коммуникативное поведение славянских народов: русские, сербы, чехи, словаки, поляки Воронеж: Востоки, 2004, 53-70.

[Maslova Alina Û. «Kommunikema kak komponent processa obŝeniâ (na materiale èmotivnyh vyskazyvanij v russkom i serbskom âzykah)». [V:] P. Piper, I. A. Sternin (red.) Kommunikativnoe povedenie. Vyp. 19. Kommunikativnoe povedenie slavânskih narodov: russkie, serby, čehi, slovaki, polâki Voronež: Vostoki, 2004, 53-70]

Маслова, Алина Ю. «Конвенциональные косвенные директивы в форме вопроса (на материале русского и сербского языков)» [В:] И. А.Стернин Л. Шипелевич (ред.) Коммуникативное поведение славянских народов. Вып 28. Варшава: Институт русистики, 2007, 123-131.

[Maslova, Alina I u. «Konvent sional'nye kosvennye direktivy v forme voprosa (na materiale russkogo i serbskogo i azykov)» [V:] I.A.Sternin L.Shipelevich (red.) Kommunikativnoe povedenie slavi anskikh narodov. Vyp 28. Varshava: Institut rusistiki, 2007, 123-131]

Персональный сайт Иосифа Абрамовича Стернина: < http://sterninia.ru/ > датум

[Personal'ny̆̌ saĭt Iosifa Abramovicha Sternina: < http://sterninia.ru/ >датум]

Пипер, Предраг, Иосиф Абрамович Стернин,. «О контрастивном изучении коммуникативного поведения близкородственных народов (русская и сербская коммуникативны культуры)» [В:] И. А. Стернин. П. Пипер (ред.) Коммуникативное поведение словянских народов. Вып. 19. Воронеж: Истоки, 2004, 3-10.

[Piper, Predrag, Iosif Abramovich Sternin. «O kontrastivnom izuchenii kommunikativnogo povedeniiâ blizkorodstvennykh narodov (russkaiā i serbskaiā kommunikativny kul'tury)» [V:] I. A. Sternin. P. Piper (red.) Kommunikativnoe povedenie sloviânskikh narodov. Vyp. 19. Voronezh: Istoki, 2004, 3-10]

Пипер, Предраг «Прилагательное руски в вербальных ассоциациях сербов».» [В:] П. Пипер, И. А. Стернин (ред.) Коммуникативное поведение. Вып. 19. Коммуникативное поведение славянских народов: русские, сербы, чехи, словаки, поляки Воронеж: Востоки, 2004, 183-188.

[Piper, Predrag «Prilagatel'noe ruski v verbal'nyh associaciâh serbov». » [V:] P. Piper, I. A. Sternin (red.) Kommunikativnoe povedenie. Vyp. 19. Kommunikativnoe povedenie slavânskih narodov: russkie, serby, čehi, slovaki, polâki Voronež: Vostoki, 2004, 183-188]

Пипер, Предраг «Как дела? О контактоустанавливающих диалогах в русском и сербском языках» [В:] П. Пипер, И. А. Стернин (ред.) Коммуникативное поведение словянских народов. Вып. 22. Воронеж: Истоки, 2006, 3-13.

[Piper, Predrag «Kak dela? O kontaktoustanavlivai ushchikh dialogakh v russkom i serbskom i azykakh« [V:] P. Piper, I. A. Sternin (red.) Kommunikativnoe povedenie slovnskikh narodov. Vyp. 22. Voronezh: Istoki, 2006, 3-13] 
Попович, Людмила В. «Жесты как невербальные и фразеологизированные диалогемы русских и сербов». [В:] П. Пипер, И. А. Стернин (ред.) Коммуникативное поведение. Вып. 19. Коммуникативное поведение славянских народов: русские, сербы, чехи, словаки, поляки Воронеж: Востоки, 2004, 39-53.

[Popovič, Lûdmila V. «Žesty kak neverbal'nye i frazeologizirovannye dialogemy russkih i serbov» [V:] P. Piper, I. A. Sternin (red.) Kommunikativnoe povedenie. Vyp. 19. Kommunikativnoe povedenie slavânskih narodov: russkie, serby, čehi, slovaki, polâki Voronež: Vostoki, 2004, 39-53]

Попович, Людмила «Дискурс публичных надписей в коммуникативном поведении русских и сербов». [В:] И. А. Стернин. П. Пипер (ред.) Коммуникативное поведение словянских народов. Вып. 22. Воронеж: Истоки, 2006, 61-83.

[Popovič, Lûdmila «Diskurs publičnyh nadpisej v kommunikativnom povedenii russkih i serbov». [V:] I. A. Sternin. P. Piper (red.) Kommunikativnoe povedenie slovânskih narodov. Vyp. 22. Voronež: Istoki, 2006, 61-83]

Правда, Елена А. «Некоторые особенности коммуникативного поведения представителей сербскоязычной культуры.» [В:] П. Пипер, И. А. Стернин (ред.) Коммуникативное поведение словянских народов. Вып. 19. Воронеж: Истоки, 2004, 70-90.

[Pravda, ElenaA. «Nekotorye osobennosti kommunikativnogo povedenii a predstavitele serbskoi azychnoĭ kul'tury. « [V:] P. Piper, I. A. Sternin (red.) Kommunikativnoe povedenie slovi anskikh narodov. Vyp. 19. Voronezh: Istoki, 2004, 70-90]

Правда, Елена А., Татьяна В. Яурова «Русские в восприятии сербов (экспериментальное исследование стереотипов восприятия)». [В:] П. Пипер, И. А. Стернин (ред.) Коммуникативное поведение. Вып. 19. Коммуникативное поведение славянских народов: русские, сербы, чехи, словаки, поляки Воронеж: Востоки, 2004, 194-199.

[Pravda, Elena A., Tat'âna V. Âurova «Russkie v vospriâtii serbov (èksperimental'noe issledovanie stereotipov vospriâtiâ)». [V:] P. Piper, I. A. Sternin (red.) Kommunikativnoe povedenie. Vyp. 19. Kommunikativnoe povedenie slavânskih narodov: russkie, serby, čehi, slovaki, polâki Voronež: Vostoki, 2004, 194-199]

Прохоров, Юрий Евгеньевич. Иосиф Абрамович Стернин. Русские: коммуникативное поведение. Москва: Флинта, 2006.

[Prokhorov, I uriǐ Evgen'evich. Iosif Abramovich Sternin. Russkie: kommunikativnoe povedenie. Moskva: Flinta, 2006]

Стернин, Иосиф Абрамович. «О понятии коммуникативного поведения». Kommunikativ-funktionale Sprachbetrachtung. Halle: 1989, 279-282.

[Sternin, Iosif Abramovich. «O poni ${ }^{\circledR}$ atii kommunikativnogo povedenii ${ }^{\imath}$ »». Kommunikativ-funktionale Sprachbetrachtung. Halle: 1989, 279-282]

Стернин, Иосиф Абрамович. «Основные особенности русской коммуникативной культуры». [В:] И. А. Стернин. П. Пипер (ред.) Коммуникативное поведение словняских народов. Вып. 19. Воронеж: Истоки, 2004, 10-25.

[Sternin, Iosif Abramovich. «Osnovnye osobennosti russkoǐ kommunikativnoŭ kul'tury». [V:] I. A. Sternin. P. Piper (red.) Kommunikativnoe povedenie slovni ^askikh narodov. Vyp. 19. Voronezh: Istoki, 2004, 10-25]

Стернин, Иосиф Абрамович. Модели описания коммуникативного поведения. Воронеж: Гарант, 2000, 27 стр. Изд. 2. испр. 2015, 52 стр.

[Sternin, Iosif Abramovich. Modeli opisanii a kommunikativnogo povedenii a. Voronezh: Garant, 2000, 27 str. Izd. 2. ispr. 2015, 52 str.] 
Дуня Радоевич

\title{
КОММУНИКАТИВНАЯ КУЛЬТУРА КАК ПРЕДМЕТ КОНФРОНТАЦИОННЫХ РУССКО-СЕРБСКИХ ИССЛЕДОВАНИЙ
}

\begin{abstract}
Резюме
Язык - это семантический код для обмена идеями, значениями и мыслями, и его изучение как культурного феномена предполагает комплексное описание его составных частей, включая коммуникативное поведение. Благодаря синтезу филологических и социоантропологических наук эта молодая лингвистическая дисциплина позволяет построить полную картину национального коммуникативного поведения одного народа. Большинство ученых и исследователей подчеркивают важность адекватного, стандартизированного, коммуникативного поведения членов языкового и культурного сообщества, а уважение норм и традиций считается одной из важнейших культурных и педагогических задач.

Различия в национальных стереотипах существенно влияют на понимание между носителями двух и более этнических групп. Противопоставление характера и теоретическая и практическая обработка необходимы, чтобы выделить наиболее ярко выраженные характеристики национального менталитета. Сравнительное описание коммуникативного поведения сербов и русских в рамках проекта Коммуникативное поведение славянских народов показало, что о различиях следует говорить не с точки зрения наличия/отсутствия национальных особенностей, а по степени их проявления и частотности.

Темы и возможности в области культуры общения многочисленны, поэтому всегда можно найти новый подход и задачу, которую необходимо решить. Дальнейшие исследования могут относиться к еще более широкой и глубокой обработке, корректировкам существующих исследований, а также к сравнению как можно большего числа национальных коммуникативных культур.

Ключевые слова: проект, коммуникативное поведение, культура общения, русский язык, сербский язык, коммуникативная ситуация.
\end{abstract}

